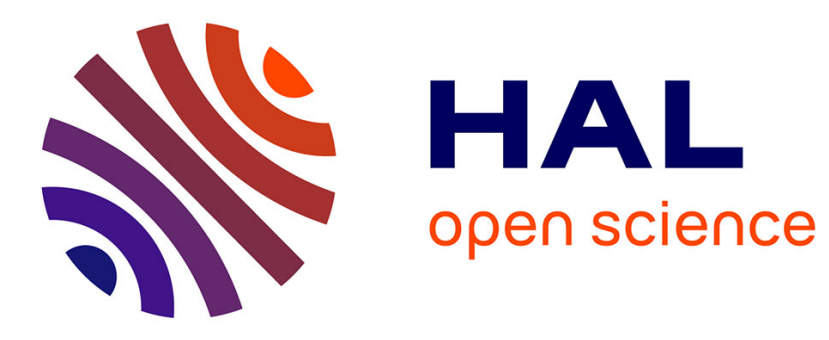

\title{
Application of chemical oxidation to remediate HCH-contaminated soil under batch and flow through conditions
}

Muhammad Usman, Oriane Tascone, Victoria Rybnikova, Pierre Faure, Khalil Hanna

\section{To cite this version:}

Muhammad Usman, Oriane Tascone, Victoria Rybnikova, Pierre Faure, Khalil Hanna. Application of chemical oxidation to remediate $\mathrm{HCH}$-contaminated soil under batch and flow through conditions. Environmental Science and Pollution Research, 2017, 24 (17), pp.14748-14757. 10.1007/s11356-0179083-5 . hal-01533328

HAL Id: hal-01533328

https://hal-univ-rennes1.archives-ouvertes.fr/hal-01533328

Submitted on 12 Oct 2017

HAL is a multi-disciplinary open access archive for the deposit and dissemination of scientific research documents, whether they are published or not. The documents may come from teaching and research institutions in France or abroad, or from public or private research centers.
L'archive ouverte pluridisciplinaire HAL, est destinée au dépôt et à la diffusion de documents scientifiques de niveau recherche, publiés ou non, émanant des établissements d'enseignement et de recherche français ou étrangers, des laboratoires publics ou privés. 


\section{Application of chemical oxidation to remediate $\mathrm{HCH}$-contaminated soil under batch and flow through conditions}

Muhammad Usman a,b, ${ }^{*}$, Oriane Tascone ${ }^{\mathrm{c}, \mathrm{d}, \mathrm{e}, \mathrm{f}}$, Victoria Rybnikova ${ }^{\mathrm{g}}$, Pierre Faure ${ }^{\mathrm{c}, \mathrm{d}}$ and Khalil Hanna ${ }^{g}$

${ }^{\text {a }}$ Department of Geosciences, Center for Applied Geosciences, University of Tübingen, 72074 Tübingen, Germany.

${ }^{\mathrm{b}}$ Institute of Soil and Environmental Sciences, University of Agriculture, Faisalabad, 38040, Pakistan.

${ }^{\mathrm{c}}$ Université de Lorraine, LIEC, UMR7360, Vandœuvre-lès-Nancy, F-54505, France.

${ }^{\mathrm{d}}$ CNRS, LIEC, UMR7360, Vandœuvre-lès-Nancy, F-54505, France.

'Université de Lorraine, LCPME, UMR7564, Vandœuvre-lès-Nancy, F-54505, France.

${ }^{\mathrm{f}}$ CNRS, LCPME, UMR7564, Villers Les Nancy, F-54600, France.

${ }^{\mathrm{g}}$ Ecole Nationale Supérieure de Chimie de Rennes, UMR CNRS 6226, 11 Allée de Beaulieu, 35708 Rennes Cedex 7, France.

* Corresponding author:

Dr. M. Usman

Research Fellow (Alexander von Humboldt Foundation)

Department of Geosciences, Center for Applied Geosciences, University of Tübingen

Hölderlinstr. 12, 72074 Tübingen, Germany

Email: muhammad.usman@uaf.edu.pk or: musmanch@yahoo.com

Phone No.: +4970712978924

Fax: +497071295059 


\section{Abstract}

This is the first study describing the chemical oxidation of hexachlorocyclohexanes (HCHs) in contaminated soil under water-saturated and unsaturated flow through conditions. Soil contaminated with $\beta-\mathrm{HCH}\left(45 \mathrm{mg} . \mathrm{kg}^{-1}\right.$ ) and $\gamma-\mathrm{HCH}$ (lindane, $25 \mathrm{mg} . \mathrm{kg}^{-1}$ ) was sampled from former lindane waste storage site. Efficiency of following treatments was tested at circumneutral pH: $\mathrm{H}_{2} \mathrm{O}_{2}$ alone, $\mathrm{H}_{2} \mathrm{O}_{2} / \mathrm{Fe}^{\mathrm{II}}, \mathrm{Na}_{2} \mathrm{~S}_{2} \mathrm{O}_{8}$ alone, $\mathrm{Na}_{2} \mathrm{~S}_{2} \mathrm{O}_{8} / \mathrm{Fe}^{\mathrm{II}}$, and $\mathrm{KMnO}_{4}$. Experimental conditions (oxidant dose, liquid/solid ratio and soil granulometry) were first optimized in batch experiments. Obtained results revealed that increasing dose of $\mathrm{H}_{2} \mathrm{O}_{2}$ improved the oxidation efficiency while in $\mathrm{Na}_{2} \mathrm{~S}_{2} \mathrm{O}_{8}$ system, maximum $\mathrm{HCHs}$ were removed at $300 \mathrm{mM}$. However, oxidation efficiency was slightly improved by $\mathrm{Fe}^{\mathrm{II}}$-activation. Increasing the solid/liquid ratio decreased $\mathrm{HCH}$ removal in soil samples crushed to $500 \mu \mathrm{m}$ while an opposite trend was observed for $2 \mathrm{~mm}$ samples. Dynamic column experiments showed that oxidation efficiency followed the order $\mathrm{KMnO}_{4}>\mathrm{Na}_{2} \mathrm{~S}_{2} \mathrm{O}_{8} / \mathrm{Fe}^{\mathrm{II}}>\mathrm{Na}_{2} \mathrm{~S}_{2} \mathrm{O}_{8}$ whatever the flow condition, whereas the removal extent declined at higher flow rate (e.g. $\sim 50 \%$ by $\mathrm{KMnO}_{4}$ at $0.5 \mathrm{~mL} / \mathrm{min}$ as compared to $\sim 30 \%$ at $2 \mathrm{~mL} / \mathrm{min}$ ). Both $\mathrm{HCH}$ removal and oxidant decomposition extents were found higher in saturated columns than the unsaturated ones. While no significant change in relative abundance of soil mineral constituents was observed before and after chemical oxidation, more than $60 \%$ of extractable organic matter was lost after chemical oxidation, thereby underscoring the non-selective behavior of chemical oxidation in soil. Due to the complexity of soil system, chemical oxidation has rarely been reported under flow through conditions, and therefore our findings will have promising implications in developing remediation techniques under dynamic conditions closer to field applications.

Keywords: HCHs; Lindane; Soil remediation; chemical oxidation; column; saturated and unsaturated conditions. 


\section{Introduction}

The Stockholm Convention on Persistent Organic Pollutants (POPs), an international environmental treaty, recently (in 2009) classified three hexachlorocyclohexanes (HCHs) namely $\alpha-\mathrm{HCH}, \beta-\mathrm{HCH}$, and $\gamma-\mathrm{HCH}$ (lindane) as POPs (Vijgen et al. 2011). Due to their global usage, strong toxicity, environmental persistence and bio-accumulative nature, HCHs appear as ubiquitous pollutants in the environment (Li et al. 2011, Vijgen et al. 2011). Among $\mathrm{HCHs}$, lindane is one of the widely investigated organochlorine pesticide in the last few decades. It has been estimated that the global usage of lindane was 600,000 tons as broadspectrum pesticide in the second half of the $20^{\text {th }}$ century (Vijgen et al. 2011, Voldner \& Li 1995, Willett et al. 1998). Moreover, production of one ton of lindane generates approximately 6-10 tons of waste containing other $\mathrm{HCH}$ isomers. According to a recent estimation, 4.8 million tons of lindane manufacturing waste may still be present in the environment (Manonmani 2011). Disposal of such huge waste has led to the creation of many dumpsites, which ultimately become the source of $\mathrm{HCH}$ contamination. Present study also concerns HCH contaminated soil (located in Northeastern France) that was encapsulated at a former lindane waste storage site. Due to the spread of contamination from this storage site, traces of lindane were detected in ground water and the surrounding soil.

Due to the associated environmental concerns, there is growing interest in the development of new and effective technologies to remove HCHs. In recent years, advanced oxidation processes (AOPs) are showing promising potential to remove POPs from contaminated matrices (Cheng et al. 2016, Usman et al. 2016a). Various AOPs have been investigated to remove HCHs including persulfate oxidation (Cao et al. 2008), ozonation (Begum \& Gautam 2012), $\mathrm{H}_{2} \mathrm{O}_{2}$ assisted UV photo-degradation (Nienow et al. 2008, Nitoi et al. 2013), persulfate activated by electrochemical processes (Wacławek et al. 2015), cobalt-activated peroxymonosulfate system (Wacławek et al. 2016) and $\mathrm{Fe}^{\mathrm{II}} / \mathrm{UV} /$ peroxymonosulfate system 
(Khan et al. 2016a, b). However, all these studies were performed in aqueous solutions. Our recent batch (no flow) study was the first work to report chemical oxidations of HCHs in contaminated soils (Usman et al. 2014). We reported an efficient degradation of $\alpha, \gamma, \beta$ and $\delta-$ $\mathrm{HCH}$ in spiked sand as well as real contaminated soil by chemical oxidation (hydrogen peroxide, persulfate and permanganate) (Usman et al. 2014). Recently, Peng and co-workers (2015) investigated the use of persulfate activated by various methods including heat at $40{ }^{\circ} \mathrm{C}$, high $\mathrm{pH}$ and $\mathrm{Fe}^{\mathrm{III}}$-EDTA reagent to remove lindane in spiked soil (not real contaminated soil).

In addition to the scarcity of the data in contaminated soils, to the best of our knowledge, chemical oxidation has never been applied to remove $\mathrm{HCHs}$ in soil columns neither under water saturated nor under unsaturated conditions. Therefore, present study was aimed to investigate the chemical oxidation of $\mathrm{HCH}$ contaminated soil under flow through conditions. Indeed, column experiments with suitable soil/water ratio can provide operational parameters that are closer to in-situ or field applications. It should be noted that chemical oxidation has rarely been studied under unsaturated conditions (vadose zone) even for other organic pollutants (Laurent et al. 2012, Palmroth et al. 2006). As a matter of fact, chemical oxidationbased remediation has been almost exclusively used for treating contaminated groundwater or aquifer.

For this purpose, various chemical oxidants (hydrogen peroxide, persulfate and permanganate) were applied to degrade $\mathrm{HCHs}$ in tested soil. Prior to column tests, experimental conditions (oxidant dose, liquid/solid ratio and granulometry) were optimized in no-flow system. Then, we performed dynamic column experiments under saturated and unsaturated conditions. The influence of experimental conditions (type and dose of oxidant, flow rate or residence time, granulometry and iron activation) on oxidation efficiency was 
also investigated under flow-through conditions. $\mathrm{HCH}$ in organic extracts were quantified by using Gas Chromatography-Mass spectrometry (GC-MS).

\section{Experimental section}

\subsection{Soil samples and chemical reagents}

All reagents used in present study were of analytical grade and are detailed in Supplementary material. Contaminated soil used in the present study was sampled from a former gravel pit that was backfilled with waste of lindane and is located in Sierentz-Alsace (SA) in Northeast of France. Thousands of tons of lindane-contaminated waste were disposed in that pit by French lindane-manufacturing industry (PCUK) from 1965-1970. This industry ceased functioning in 1974 and the pit was later confined by using waterproof capsule to avoid further spread of contamination. Total weight of the encapsulated $\mathrm{HCH}$ contaminated soil and waste was estimated to be 112000 tons (Dubearnes 2006). French environmental agency (ADEME) is responsible for monitoring of tested site where traces of lindane were detected in 2003 at the base of capsule and in groundwater despite its encapsulation. Sampled soil contains relatively fine-grained fractions $(19.2 \%$ of clay and $13.8 \%$ of fine silt) with organic matter (7\%), total organic carbon (4.5\%), and $\mathrm{C} / \mathrm{N}$ ratio of 13.6 . The $\mathrm{pH}$ of soil is relatively higher ( 8.05) which might be linked to its high $\mathrm{CaCO}_{3}$ contents $(19.5 \%)$. A detailed description about properties of the tested soil is presented elsewhere (Usman et al. 2014).

\subsection{Investigation of oxidation reaction under batch conditions}

In first step, batch (no-flow) experiments were used to optimize experimental conditions for $\mathrm{H}_{2} \mathrm{O}_{2}$ and persulfate to degrade $\mathrm{HCHs}$ in contaminated soil. All oxidation tests are summarized in Table 1 and general procedure is explained in Supplementary material. First experiment evaluated the degradation efficiency at various oxidant doses including (i) $\mathrm{H}_{2} \mathrm{O}_{2}$ 
alone $(900 \mathrm{mM})$ without iron activation $\left(\mathrm{H}_{2} \mathrm{O}_{2}\right)$ and Fenton oxidation $\left(\mathrm{H}_{2} \mathrm{O}_{2} / \mathrm{Fe}^{\mathrm{II}}\right)$ by using (ii) $200 \mathrm{mM} \mathrm{H} \mathrm{O}_{2}+20 \mathrm{mM}$ soluble $\mathrm{Fe}^{\mathrm{II}}$ (dose A), (iii) $900 \mathrm{mM} \mathrm{H}_{2} \mathrm{O}_{2}+90 \mathrm{mM}$ soluble $\mathrm{Fe}^{\mathrm{II}}$ (dose C), (iv) sodium persulfate alone $(600 \mathrm{mM})$ without iron activation $\left(\mathrm{Na}_{2} \mathrm{~S}_{2} \mathrm{O}_{8}\right)$, and activated persulfate $\left(\mathrm{Na}_{2} \mathrm{~S}_{2} \mathrm{O}_{8} / \mathrm{Fe}^{\mathrm{II}}\right)$ by using (v) $100 \mathrm{mM} \mathrm{Na}_{2} \mathrm{~S}_{2} \mathrm{O}_{8}+50 \mathrm{mM}$ soluble $\mathrm{Fe}^{\mathrm{II}}$ (dose A) (vi) $600 \mathrm{mM} \mathrm{Na} 2 \mathrm{~S}_{2} \mathrm{O}_{8}+300 \mathrm{mM}$ soluble $\mathrm{Fe}^{\mathrm{II}}$ (dose C). For comparison, results corresponding to $600 \mathrm{mM} \mathrm{H} \mathrm{O}_{2}+60 \mathrm{mM}$ soluble $\mathrm{Fe}^{\mathrm{II}}$ (dose $\mathrm{B}$ ), $300 \mathrm{mM}$ sodium persulfate $+150 \mathrm{mM}$ soluble $\mathrm{Fe}^{\mathrm{II}}$ (dose B) were borrowed from Usman et al. (Usman et al. 2014). Blank experiments were also performed in water under the same conditions but without any oxidant, to study possible degradation of the HCHs. An oxidant:Fe molar ratio equal to 10:1 $\left(\mathrm{H}_{2} \mathrm{O}_{2}\right)$ and 2:1 (persulfate) was chosen in soil slurry according to the previous findings (Usman et al. 2014).

Effect of solid/liquid was evaluated by comparing chemical oxidation at different sample loadings i.e. $5 \mathrm{~g}, 10 \mathrm{~g}$ and $20 \mathrm{~g}$ of SA soil (Table 1). For each set of experiment, granulometry was also changed by sieving the soil samples through different mesh sizes $(500 \mu \mathrm{m}, 2 \mathrm{~mm}$ and $5 \mathrm{~mm}$ ) to demonstrate the impact of particle size. Soil samples having particle size of 500 $\mu \mathrm{m}$ were obtained by sieving soil samples through $2 \mathrm{~mm}$ mesh size followed by grinding.

\subsection{Chemical oxidation under flow through conditions}

Column experiments were conducted by using a glass chromatographic column of $120 \mathrm{~mm}$ length and $25 \mathrm{~mm}$ internal diameter. The main characteristics of the columns are presented in Table 2. Chemical oxidation was performed under saturated and unsaturated conditions (see Table 1 for conditions). In general procedure, contaminated soil samples corresponding to a dry mass of $20 \mathrm{~g}$ were packed in columns. After packing, the column was cautiously wetted upward with the Milli-Q water (Millipore) to obtain saturated conditions. Once the column was saturated, the column was fed upwards at the same constant flow rate with soluble $\mathrm{Fe}^{\mathrm{II}}$ solution followed by the oxidant solution (open system). Firstly, experiments were conducted 
by using soil samples having particle size of $500 \mu \mathrm{m}$, but columns were clogged up after some time probably due to small particle size. But, column experiments conducted with soil samples sieved at $2 \mathrm{~mm}$ did not show any clogging issues. Therefore, further column experiments were performed by using soil samples sieved at $2 \mathrm{~mm}$. Five oxidation treatments including $\mathrm{H}_{2} \mathrm{O}_{2}, \mathrm{H}_{2} \mathrm{O}_{2} / \mathrm{Fe}^{\mathrm{II}}, \mathrm{Na}_{2} \mathrm{~S}_{2} \mathrm{O}_{8}$ and $\mathrm{Na}_{2} \mathrm{~S}_{2} \mathrm{O}_{8} / \mathrm{Fe}^{\mathrm{II}}$ (detailed in Table 1) were firstly tested using the same oxidant doses as in no-flow and by keeping a liquid/solid ratio constant (i.e. 5 $\mathrm{g}: 20 \mathrm{ml}$ in batch, and $20 \mathrm{~g}: 80 \mathrm{ml}$ in column). Additionally, permanganate $\left(\mathrm{KMnO}_{4}\right)$ alone $(90 \mathrm{mM})$ was tested under flow through conditions based on the results of previous no-flow study (Usman et al. 2014). Blank experiments (prepared in similar way) were conducted by injecting water in soil packed column in a continuous mode at the same constant flow rate. Experiments were conducted under two different flow rates $(0.5$ and $2 \mathrm{~mL} / \mathrm{min})$ in order to investigate the influence of oxidant residence time on the $\mathrm{HCH}$ degradation in column. The flow rate was checked several times and was found constant. Once whole solution was injected, the solid samples were freeze-dried to remove water and then analyzed as explained below.

Experiments were then conducted to evaluate the impact of oxidant dose onto oxidative degradation of $\beta-\mathrm{HCH}$ under flow through conditions (Table 1). For this purpose, experiments were performed under two conditions (i) with iron activation and (iii) without iron activation by using three different oxidant doses including $100 \mathrm{mM}, 300 \mathrm{mM}$ and 600 $\mathrm{mM}$ of $\mathrm{Na}_{2} \mathrm{~S}_{2} \mathrm{O}_{8}$, and $200 \mathrm{mM}, 600 \mathrm{mM}$ and $900 \mathrm{mM}$ of $\mathrm{H}_{2} \mathrm{O}_{2}$. When activated, one porous volume of a solution containing soluble $\mathrm{Fe}^{\mathrm{II}}(60 \mathrm{mM})$ was dosed in columns before injecting oxidant solution at the same flow rate (i.e. $0.5 \mathrm{ml} / \mathrm{min}$, Table 1). Experiments were also conducted by using $30 \mathrm{mM}$ and $90 \mathrm{mM}$ of $\mathrm{KMnO}_{4}$ alone.

Experiments were also performed under unsaturated soil conditions (Table 1). Soil columns, with a length of $120 \mathrm{~mm}$ and diameter of $25 \mathrm{~mm}$, identical to those employed in saturated 
conditions were packed with $20 \mathrm{~g}$ of contaminated soil. Column conditions are detailed in Table 2. Then, these columns were fed by sprinkling of oxidant solutions with a constant flow rate of $0.5 \mathrm{~mL} / \mathrm{min}$ : i) $\mathrm{KMnO}_{4}(30 \mathrm{mM})$, ii) $\mathrm{Na}_{2} \mathrm{~S}_{2} \mathrm{O}_{8}(100 \mathrm{mM})$, iii) $\mathrm{H}_{2} \mathrm{O}_{2}$ alone $(600 \mathrm{mM})$ and iv) $\mathrm{H}_{2} \mathrm{O}_{2}$ activated by iron $\left(600 \mathrm{mM} \mathrm{H} \mathrm{H}_{2} \mathrm{O}_{2}+60 \mathrm{mM}\right.$ soluble $\left.\mathrm{Fe}^{\mathrm{II}}\right)$. The column was continuously weighed using a balance located underneath the column, to ensure a constant porosity and to avoid a significant change in water content along the experiment. Three replicates were analyzed from each column. All results were expressed as a mean value of the three values and standard deviation of the three replicates was less than 5\%. All experiments were performed at room temperature $\left(20-22{ }^{\circ} \mathrm{C}\right)$. The column test was stopped and the packed soil was analyzed, once all injected volume was exhausted. It should be noted that $\mathrm{HCH}$ concentration was monitored in solid phase through extraction/analysis procedures (as explained in the following section), and therefore no classical breakthrough curve $\left(\mathrm{C} / \mathrm{C}_{0}\right.$ as a function of PV, porous volume) can be plotted in this study. Analysis of the column effluent (after liquid-liquid extraction with chloroform) revealed that outflow concentration of HCHs was almost zero, thereby underscoring the absence of $\mathrm{HCH}$ mobilization from the column. Concentration of remaining $\mathrm{H}_{2} \mathrm{O}_{2}$ and $\mathrm{Na}_{2} \mathrm{~S}_{2} \mathrm{O}_{8}$ oxidant were determined by iodometric titration, and $\mathrm{KMnO}_{4}$ concentrations by colorimetric titration (Barnes et al. 2005, Brumblay 1971).

\subsection{Extraction and analysis}

The freeze-dried samples were extracted in chloroform and were analyzed by GC-MS as detailed in supplementary material. 


\section{Results and discussion}

\subsection{Optimization of HCH degradation under no-flow conditions}

Sampled soil (SA), crushed to $500 \mu \mathrm{m}$, was analyzed to determine the $\mathrm{HCH}$ content and results obtained by GC-MS revealed the presence of $\gamma-\mathrm{HCH}$ (lindane, $25 \mathrm{mg} . \mathrm{kg}^{-1}$ ) and $\beta-$ $\mathrm{HCH}$ (45 mg. $\mathrm{kg}^{-1}$ ). These soil samples were subjected to chemical oxidation at various oxidant doses (Table 1) under no-flow conditions without $\mathrm{pH}$ adjustment. Degradation of both isomers was calculated per their initial contents and concerned data after $24 \mathrm{~h}$ of reaction is represented in Figure 1. For comparison purposes, values corresponding to dose B of $\mathrm{H}_{2} \mathrm{O}_{2} / \mathrm{Fe}^{\mathrm{II}}$ and $\mathrm{Na}_{2} \mathrm{~S}_{2} \mathrm{O}_{8} / \mathrm{Fe}^{\mathrm{II}}$ were borrowed from a previous study (Usman et al. 2014). Almost no $\mathrm{HCH}$ degradation was observed in blank experiments. In $\mathrm{H}_{2} \mathrm{O}_{2} / \mathrm{Fe}^{\mathrm{II}}$ treatments, dose $\mathrm{C}$ exhibited stronger removal of both $\beta-\mathrm{HCH}(\sim 70 \%)$ and $\gamma-\mathrm{HCH}(\sim 90 \%)$ (Fig. 1). Use of $\mathrm{Na}_{2} \mathrm{~S}_{2} \mathrm{O}_{8} / \mathrm{Fe}^{\mathrm{II}}$ (dose $\mathrm{B}$ and $\mathrm{C}$ ) also removed up to $\sim 40 \%$ of $\beta-\mathrm{HCH}$ and $\sim 90 \%$ of $\gamma-\mathrm{HCH}$. Increasing oxidant dose exhibited positive influence on oxidation efficiency in $\mathrm{H}_{2} \mathrm{O}_{2} / \mathrm{Fe}^{\mathrm{II}}$ treatments while no pronounced effect was observed beyond dose $\mathrm{B}$ of $\mathrm{Na}_{2} \mathrm{~S}_{2} \mathrm{O}_{8} / \mathrm{Fe}^{\mathrm{II}}$ in persulfate oxidation. Similarly, no significant improvement in degradation efficiency was reported beyond an optimum oxidant dose during radical based oxidation of polycyclic aromatic hydrocarbons in contaminated soils that was correlated to the radical scavenging (Lemaire et al. 2013). It is worthy to note that both oxidants when applied without iron activation also effectively degrade both $\beta-\mathrm{HCH}\left(37 \%\right.$ and $30 \%$ by $\mathrm{H}_{2} \mathrm{O}_{2}$ and $\mathrm{Na}_{2} \mathrm{~S}_{2} \mathrm{O}_{8}$ respectively) and lindane ( $75 \%$ and $89 \%$ by $\mathrm{H}_{2} \mathrm{O}_{2}$ and $\mathrm{Na}_{2} \mathrm{~S}_{2} \mathrm{O}_{8}$ respectively). This strong degradation without $\mathrm{Fe}^{\mathrm{II}}$ activation could be linked to the presence of native iron minerals (2.47 wt $\%$ of $\mathrm{Fe}_{2} \mathrm{O}_{3}$ ) or transition metals (Table S1 in Supplementary material) present in the tested soil that might catalyze the chemical oxidants (Ahmad et al. 2010, Anipsitakis \& Dionysiou 2004, Usman et al. 2014). Moreover, oxidants can also contribute by directly 
oxidizing the pollutants via non-radical pathways or direct electron transfer process as explained previously (Usman et al. 2014). These results also reveal that $\mathrm{Fe}^{\mathrm{II}}$ activation did not result in pronounced increase in oxidation efficiency that might be caused by its precipitation at relatively high $\mathrm{pH}$ of tested soil (Matta et al. 2008, Tamura et al. 1980). A very slight decrease in $\mathrm{pH}$ (from 8.05 to 7.90 ) was observed after introduction of reactants that stayed almost constant during the whole course of reaction probably due to the soil's high carbonate content $(\sim 20 \%)$ or buffering capacity. It should be noted that an acidic $\mathrm{pH}$ is required to keep $\mathrm{Fe}^{\mathrm{II}}$ in soluble form for optimum efficiency of traditional Fenton oxidation (Safarzadeh-Amiri et al. 1996, Usman et al. 2016a). In previous reports, the soluble $\mathrm{Fe}^{\mathrm{II}}$ was neither able to catalyze Fenton oxidation (Usman et al. 2012a) nor persulfate oxidation (Usman et al. 2012b) at circumneutral $\mathrm{pH}$ to treat PAHs in former coking plant soils. Therefore, it was suggested that iron minerals or chelating agents could be used instead of soluble $\mathrm{Fe}^{\mathrm{II}}$ to catalyze chemical oxidation at circumneutral pH (Usman et al. 2012a, b). This initial acidification in traditional Fenton oxidation could be costly, impractical in soils due to their high buffering capacity and could negatively affect the soil quality and successive vegetation (Laurent et al. 2012, Sirguey et al. 2008). Therefore, present study was performed without $\mathrm{pH}$ adjustment to avoid initial acidification and/or injection of multiple reagents (chelating agents or iron minerals). Furthermore, acidification of large volume in soils would be impractical for column experiments or in-situ high scale applications.

Obtained GC-MS chromatograms were almost identical before or after oxidation, suggesting that no new reaction products can be detected under our analytical conditions. This may be partially due to the very fast reaction kinetics of sulfate and hydroxyl radicals with possible by-products (if formed), and/or lower concentration (below the detection limit) of these unknown compounds. In aqueous solution, Nitoi and co-workers (2013) revealed the formation of chlorinated by-products such as hexachlorobenzene and trichlorobenzene during 
the photo-Fenton oxidation of lindane, which disappeared completely after $4 \mathrm{~h}$ of reaction. Complete degradation was also achieved during oxidation of lindane by $\mathrm{Fe}^{\mathrm{II}}$-activated persulfate (2,3,4-trichlorophenol was formed as a primary by-product but was subsequently degraded over time) (Cao et al. 2008) or oxidation of $\gamma-\mathrm{HCH}$ by thermally-activated persulfate (Peng et al. 2015).

It should be noted that non-selective behavior of chemical oxidation could also degrade the non-target organic compounds. Therefore, a significant loss of extractable organic matter (60$80 \%$ ) was observed after chemical oxidation in the investigated soil. However, contents of metal oxides like $\mathrm{Al}_{2} \mathrm{O}_{3}, \mathrm{TiO}_{2}, \mathrm{CaO}$ and $\mathrm{P}_{2} \mathrm{O}_{5}$ remained almost similar (Table $\mathrm{S} 1$ in Supplementary material) whatever the used oxidant. In experiments using $\mathrm{Fe}^{\mathrm{II}}$ as catalyst, higher iron content was observed in the treated soil (Table S1).

Our results also indicate that $\beta-\mathrm{HCH}$ was more recalcitrant than lindane as previously observed (Usman et al. 2014). This recalcitrant behavior of $\beta-\mathrm{HCH}$ could be explained by its higher chemical and metabolic stability due to the absence of axial-orientated chlorines and lowest Henry's law constant (Beurskens et al. 1991, Johri et al. 1998). Due to its higher recalcitrance and greater concentration in the tested soil, rest of the experiments focused only on the degradation of $\beta-\mathrm{HCH}$.

Experiments were also conducted with different solid loading (solid/liquid ratio) and particle sizes, in order to optimize the experimental conditions for column studies. For this purpose, chemical oxidation treatments (Table 1) were applied at various soil loadings (5 g, $10 \mathrm{~g}$ and $20 \mathrm{~g})$ and particle sizes $(500 \mu \mathrm{m}, 2 \mathrm{~mm}$ and $5 \mathrm{~mm})$ (Fig. S1 in Supplementary material). Obtained results for the soil sample having $500 \mu \mathrm{m}$ (Fig. S1a) indicated that degradation of $\beta-$ $\mathrm{HCH}$ decreased with an increase in solid loading. This was expected because $\mathrm{HCH}$ content and oxidant demand (radical scavenging) increased with an increase in sample size (from 5 to 
$20 \mathrm{~g})$ that would decrease oxidation efficiency. On the other hand, an opposite trend was observed for samples with $2 \mathrm{~mm}$ particle size where degradation efficiency increased with an increase in solid loading (Fig. S1b). Quantification of initial $\beta-\mathrm{HCH}$ content revealed a difference of $30 \mathrm{ppm}$ between soil samples having particle size of $500 \mu \mathrm{m}(43 \mathrm{ppm})$ and 2 $\mathrm{mm}(73 \mathrm{ppm})$ which suggests that $40 \%$ of $\beta-\mathrm{HCH}$ was lost when $2 \mathrm{~mm}$ samples were grinded to obtain $500 \mu \mathrm{m}$. Soil samples sieved at $2 \mathrm{~mm}$ contain a higher initial pollutant content with higher availability that ultimately could enhance the degradation. Availability of the pollutant was found as the main limiting factor controlling the efficiency of subsequent chemical oxidation (Jonsson et al. 2007, Usman et al. 2012a, 2016b). Thus, increasing the sample size (from $5 \mathrm{~g}$ to $20 \mathrm{~g}$ ) for $2 \mathrm{~mm}$ samples increases such free fraction of $\beta-\mathrm{HCH}$ that is more easily degradable. On the other hand, no general degradation trend was observed during oxidation of different solid loading at $5 \mathrm{~mm}$ (Fig. S1c), probably due to the higher heterogeneity of the tested samples (with larger particle size, $5 \mathrm{~mm}$ ).

\subsection{Investigation of $\mathrm{HCH}$ degradation under flow through conditions}

Firstly, column experiments (Table 1: column experiments $I$ ) were performed by using soil samples having $500 \mu \mathrm{m}$ but severe clogging-up was observed due to lower particle size and

poor hydraulic conductivity or permeability in column. Clogging problem persisted even when the tested soil was mixed with sand $(30 \% \mathrm{w} / \mathrm{w})$ to improve its porosity. Therefore, further column experiments were conducted by using soil samples having $2 \mathrm{~mm}$ particle size where no such problems were observed. Efficiency of chemical oxidation was tested under saturated flow through conditions by injecting oxidant solution at two different flow rates $(0.5$ $\mathrm{mL} / \mathrm{min}$ and $2 \mathrm{~mL} / \mathrm{min}$ ) and the obtained results are presented in Figure 2. The permanganate was tested under flow through conditions based on the results of a previous no-flow study (Usman et al. 2014). The decomposition extents of oxidants were determined for Column experiment I (Table 1) at $0.5 \mathrm{ml} / \mathrm{min}$ by measuring the final concentration in column effluents 
at the end of reaction. However, no breakthrough curve (i.e. oxidant concentration versus porous volume number or time) could be determined. The decomposition extent of oxidant lies at $100 \%$ for $\mathrm{H}_{2} \mathrm{O}_{2}$ or $\mathrm{H}_{2} \mathrm{O}_{2} / \mathrm{Fe}^{\mathrm{II}}, 32 \%$ and $56 \%$ for $\mathrm{Na}_{2} \mathrm{~S}_{2} \mathrm{O}_{8}$ and $\mathrm{Na}_{2} \mathrm{~S}_{2} \mathrm{O}_{8} / \mathrm{Fe}^{\mathrm{II}}$, respectively, and only $30 \%$ for $\mathrm{KMnO}_{4}$.

Almost no degradation was observed in blank experiments where no oxidant was used. No traces of $\beta-\mathrm{HCH}$ in outflow solution (i.e. column effluent) were observed stating the absence of its mobilization from column. Obtained results (Fig. 2) indicated that oxidation efficiency followed this order $\mathrm{KMnO}_{4}>\mathrm{Na}_{2} \mathrm{~S}_{2} \mathrm{O}_{8} / \mathrm{Fe}^{\mathrm{II}}>\mathrm{H}_{2} \mathrm{O}_{2} / \mathrm{Fe}^{\mathrm{II}}>\mathrm{Na}_{2} \mathrm{~S}_{2} \mathrm{O}_{8}>\mathrm{H}_{2} \mathrm{O}_{2}$ at $0.5 \mathrm{~mL} / \mathrm{min}$ (Fig. 2). A similar trend was observed $\left(\mathrm{KMnO}_{4}>\mathrm{Na}_{2} \mathrm{~S}_{2} \mathrm{O}_{8} / \mathrm{Fe}^{\mathrm{II}}>\mathrm{Na}_{2} \mathrm{~S}_{2} \mathrm{O}_{8}\right)$ but with lower degradation efficiency when flow rate increased to $2 \mathrm{~mL} / \mathrm{min}$. Lower degradation at high flow rate could be attributed to lower residence time of oxidants in columns. But injection of hydrogen peroxide $\left(\mathrm{H}_{2} \mathrm{O}_{2} / \mathrm{Fe}^{\mathrm{II}}\right.$ or $\mathrm{H}_{2} \mathrm{O}_{2}$ alone $)$ at higher flow rate did not yield any results due to the significant release of heat and creation of strong pressure in column ultimately leading to its blockage. Despite the same solid/liquid ratio and oxidant dose used in batch as well as in dynamic column experiments, a higher degradation extent was observed in column experiments. The greater efficiency in column could be correlated to the difference in experimental conditions between no-flow and flow regimes. Indeed, oxidant injected at a constant flow rate reaches progressively the column bed, in contrast to the single addition in batch. This could avoid parasite reactions (e.g. self-decomposition of $\mathrm{H}_{2} \mathrm{O}_{2}$, scavenging effects, etc.), which generally occur when a high amount of oxidant (with or without catalyst) comes into contact spontaneously with soil. Similar observations were reported in the batch system when sequential addition of oxidant was found more efficient than single addition (Kong et al. 1998, Tseng et al. 2012). Analyses of tested soil after chemical oxidation revealed that metal oxides (Table $\mathrm{S} 1$ ) represented similar trend as in batch conditions (relative abundance of $\mathrm{Al}_{2} \mathrm{O}_{3}, \mathrm{Fe}_{2} \mathrm{O}_{3}, \mathrm{TiO}_{2}$ and $\mathrm{P}_{2} \mathrm{O}_{5}$ did not significantly change and almost similar 
increase in $\mathrm{Na}_{2} \mathrm{O}$ when $\mathrm{Na}_{2} \mathrm{~S}_{2} \mathrm{O}_{8}$ was used). However contrary to batches, soil iron content did not increase when soluble $\mathrm{Fe}^{\mathrm{II}}$ was used, probably because it flushed out in column effluents. It is worthy to note that entire system (water + solid) in batches is subjected to freeze-drying prior to extraction/analysis, and thus dissolved components are also retained in the posttreated soil.

Although $\mathrm{KMnO}_{4}$ has been shown to be the least reactive oxidant to degrade $\mathrm{HCH}$ under noflow conditions as demonstrated in our previous study (Usman et al. 2014), it becomes the most active one under flow through conditions. This discrepancy in efficiency of $\mathrm{KMnO}_{4}$ under batch and column conditions could not come from the stabilization of $\mathrm{HCH}$ isomers in $\mathrm{MnO}_{2}$ generated from the decomposition of $\mathrm{KMnO}_{4}$ (Kao et al. 2008, Yan \& Schwartz 1999), since the latter is supposed to occur in both batch and column systems. It may be, however, possible that formed $\mathrm{MnO}_{2}$ interferes with $\mathrm{KMnO}_{4}$ and thus influences the oxidation efficiency, and this "side reaction" must be different in batch vs column flow systems. Indeed, contact between parent compound (e.g. oxidant) and oxidation byproducts may be likely reduced under flow-through conditions, since byproducts could be flushed out from the column. Although this hypothesis is the most plausible one, this issue needs further investigations. It should be noted that preliminary extraction tests and GC-MS analyses (data not shown) showed no impact of addition of synthetic $\mathrm{MnO}_{2}$ on the recovery of $\mathrm{HCHs}$ during extraction.

Obtained results indicated that oxidation efficiency was decreased with an increase in flow rate or with a decrease in residence time (Fig. 2), suggesting that kinetic limitations may occur at a high flow rate $(2 \mathrm{~mL} / \mathrm{min})$. In the absence of physical diffusion, preferential pathways or stagnant zones, the extent of reaction that occurs in column is controlled by chemical oxidation kinetic and residence time. The higher the flow rate the lesser the contact time between oxidant and target contaminant, and therefore the lesser the oxidation reaction 
efficiency. To test the impact of kinetic limitation in column, Damköhler number (Da) that represents the ratio of hydrodynamic residence time to characteristic time for chemical reaction in the column is generally used (Hanna et al. 2012, Rusch et al. 2010). Unfortunately, the lack of kinetic data of $\mathrm{HCH}$ in soil (oxidation was determined only at $24 \mathrm{~h}$ ) and mass transfer rate in column does not allow the estimation of Da number. Nevertheless, the present findings showed clearly that a lower flow rate $(0.5 \mathrm{~mL} / \mathrm{min})$ could ensure a sufficient residence time to reach greater oxidation extent (e.g. $50 \%$ using $\mathrm{KMnO}_{4}$ ).

Further experiments were conducted by using various oxidant doses (detailed in Table 1: column experiments II) injected at a flow rate of $0.5 \mathrm{~mL} / \mathrm{min}$. Obtained results (Fig. 3) indicate that application of $600 \mathrm{mM}$ of $\mathrm{H}_{2} \mathrm{O}_{2}$ resulted in higher oxidation of $\beta-\mathrm{HCH}(17-29 \%)$ as compared to the $200 \mathrm{mM}(16-17 \%)$ or $900 \mathrm{mM}(8 \%)$ of oxidant. Relatively poor degradation of $\beta-\mathrm{HCH}$ at elevated oxidant dose of $900 \mathrm{mM}$ could be linked to the scavenging of $\mathrm{OH}^{\bullet}$ radicals by $\mathrm{H}_{2} \mathrm{O}_{2}$ that becomes of great importance at much higher concentration (Wang et al. 2000). Degradation efficiency was almost similar (16-17\%) if $\mathrm{H}_{2} \mathrm{O}_{2}(200 \mathrm{mM})$ was applied with or without iron activation. But, $\mathrm{Fe}^{\mathrm{II}}$ activation of $600 \mathrm{mM} \mathrm{H}_{2} \mathrm{O}_{2}$ resulted in higher degradation (29\%) than without iron addition $(17 \%)$. On the other hand, $\mathrm{Fe}^{\mathrm{II}}$ activation has a negative impact on oxidation efficiency of $\mathrm{Na}_{2} \mathrm{~S}_{2} \mathrm{O}_{8}$ at various oxidant doses except for $600 \mathrm{mM}$. This could be attributed to the rapid decomposition of persulfate due to $\mathrm{Fe}^{\mathrm{II}}$ activation, and scavenging effect of sulfate radicals by $\mathrm{Fe}^{\mathrm{II}}$ before it has an opportunity to react with the target contaminants (Romero et al. 2010, Zhao et al. 2013). Scavenging of sulfate radicals by $\mathrm{Fe}^{\mathrm{II}}$ especially at higher concentration can be detrimental for oxidation efficiency (Romero et al. 2010). In case of $\mathrm{Na}_{2} \mathrm{~S}_{2} \mathrm{O}_{8}$, the most effective dose seems to be the $600 \mathrm{mM}$ with $50 \%$ of $\beta-\mathrm{HCH}$ degradation. However, a degradation extent of $34 \%$ was obtained with lower dose of $100 \mathrm{mM}$ (6x less than $600 \mathrm{mM}$ ) without iron activation that seems as more economical dose if degradation efficiency/oxidant dose is considered. The 
$\mathrm{KMnO}_{4}$ showed strong efficiency to degrade $\beta-\mathrm{HCH}$ with similar oxidation efficiency at both doses (48\% and $49 \%$ of degradation with $30 \mathrm{mM}$ and $90 \mathrm{mM}$ respectively) and thus rendering $30 \mathrm{mM}$ more economical. To the best of our knowledge, no data about $\mathrm{HCH}$ oxidation in column is available in the literature and therefore it is difficult to make a fair comparison of our findings with the literature.

Experiments were then conducted under unsaturated conditions by using the most efficient systems obtained in saturated systems, i.e. $\mathrm{KMnO}_{4}(30 \mathrm{mM}), \mathrm{Na}_{2} \mathrm{~S}_{2} \mathrm{O}_{8}(100 \mathrm{mM})$, iii) $\mathrm{H}_{2} \mathrm{O}_{2}$ alone $(600 \mathrm{mM})$ and iv) $\mathrm{H}_{2} \mathrm{O}_{2} / \mathrm{Fe}^{\mathrm{II}}\left(600 \mathrm{mM} \mathrm{H} \mathrm{H}_{2}+60 \mathrm{mM}\right.$ soluble $\mathrm{Fe}^{\mathrm{II}}$ ) (Fig. 4). However, columns designated to $\mathrm{H}_{2} \mathrm{O}_{2}$ application (with or without catalyst) were not analyzed due to the very strong reaction leading to column plugging and ultimately the overflow from the column. Indeed, the sprinkled $\mathrm{H}_{2} \mathrm{O}_{2}$ immediately decomposes at the top of soil, which creates a kind of foam preventing circulation of the sprinkler solution.

Obtained results (Fig. 4) indicated that $\mathrm{KMnO}_{4}$ resulted in $24 \%$ of $\beta-\mathrm{HCH}$ degradation as compared to the $18 \%$ by $\mathrm{Na}_{2} \mathrm{~S}_{2} \mathrm{O}_{8}$ (Fig. $4 \mathrm{a}$ ). It should be noted that single reagents $\left(\mathrm{Na}_{2} \mathrm{~S}_{2} \mathrm{O}_{8}\right.$ or $\mathrm{KMnO}_{4}$ ) caused such degradation and that could be advantageous in soils where injection of multiple reactants could be difficult. It was also observed that regardless of the oxidant, degradation of $\beta-\mathrm{HCH}$ is more important for saturated conditions than unsaturated conditions. This could be explained by the presence of gas phase and/or preferential pathways through soil column under unsaturated conditions (e.g. porosity is lower in unsaturated columns, table 2). These conditions could decrease soil/oxidant contact because of the less proportion of the soil available for oxidation reaction and it will ultimately lead to lower pollutant degradation. This behavior was further confirmed by measuring the oxidant consumption in columns at the end of reaction. As shown in Figure 4b, lower decomposition extents of oxidant were noted for unsaturated columns as compared to saturated conditions. As mentioned above, the available literature severely lacks deep investigations on the chemical oxidation under 
saturated $v s$ unsaturated conditions, to be compared with our present findings. Nevertheless, other reports on the distribution of heavy metals (Plassard et al. 2000) and leaching of herbicides (Weber \& David 1982) showed that the extent of reaction (Lewis \& Sjöstrom 2010) was more important under saturated-flow conditions than that under unsaturated-flow conditions.

\section{Conclusion}

Tested soil was sampled from former $\mathrm{HCH}$ waste storage facility and was found contaminated with $\beta-\mathrm{HCH}$ and lindane $(\gamma-\mathrm{HCH})$. It was subjected to chemical oxidation by using hydrogen peroxide and sodium persulfate, both with and/or without soluble $\mathrm{Fe}^{\mathrm{II}}$, and permanganate. Experimental conditions were first optimized under no-flow conditions for successive chemical oxidation under flow through conditions. This study represents the following important points:

i- No-flow experiments: Chemical oxidation resulted in significant degradation of HCHs in contaminated soils without any identified by-products under our analytical settings. As expected, soluble $\mathrm{Fe}^{\mathrm{II}}$ was unable to significantly activate $\mathrm{H}_{2} \mathrm{O}_{2}$ and $\mathrm{Na}_{2} \mathrm{~S}_{2} \mathrm{O}_{8}$ at circumneutral $\mathrm{pH}$ in soil. Increasing oxidant dose improved oxidation efficiency till an optimum amount. The $\beta-\mathrm{HCH}$ showed higher recalcitrance than lindane. Degradation of $\beta-\mathrm{HCH}$ was decreased with an increase in solid loading for soil samples crushed to $500 \mu \mathrm{m}$, while an opposite trend was observed for soil samples sieved through $2 \mathrm{~mm}$. No general trend was, however, observed for soil samples at $5 \mathrm{~mm}$.

ii-Saturated column experiments: Experiments were conducted under saturated flow through conditions at two different flow rates $(0.5$ and $2 \mathrm{ml} / \mathrm{min})$ and at different oxidant doses. Higher $\beta-\mathrm{HCH}$ degradation was observed at $0.5 \mathrm{~mL} / \mathrm{min}$ due to higher residence time of oxidants in column. Moreover, saturated columns also resulted in higher $\mathrm{HCH}$ degradation 
than no-flow conditions especially for permanganate that was the most effective oxidant under flow through conditions.

iii- Unsaturated column experiments: Significant degradation of $\beta-\mathrm{HCH}$ was observed under unsaturated conditions by using permanganate and persulfate. Lower $\mathrm{HCH}$ removal as well as oxidant decomposition extents were observed in unsaturated columns as compared to saturated conditions. Obtained results indicated that such degradation was achieved by using single reagents (sodium persulfate or permanganate alone) which could be advantageous in soils where injection of multiple reagents could be problematic. As a matter of fact, the use of chemical oxidation has been rarely reported under flow through conditions to remediate contaminated soils due to the complexity of system. Although a small difference in degradation performance was observed in saturated-flow vs. unsaturated-flow conditions, our findings showed that chemical oxidation is effective to degrade $\mathrm{HCHs}$ in both investigated systems. Therefore, these results are very promising to develop strategies to remediate subsurface soils (i.e. unsaturated conditions) as well as contaminated aquifer (i.e. saturated conditions).

\section{Acknowledgment}

The financial support from French organization ADEME “Agence de l'Environnement et de la Maîtrise de l'Energie" Convention N0972C0016 is gratefully acknowledged. The authors are also thankful to Prof. C. Ruby (UMR7564 LCPME) and C. Lorgeoux (UMR7359 Géoressources) for supporting this work. 


\section{References}

Ahmad M, Teel AL, Watts RJ (2010): Persulfate activation by subsurface minerals. J. Contam. Hydrol. 115, 34-45

Anipsitakis GP, Dionysiou DD (2004): Radical Generation by the Interaction of Transition Metals with Common Oxidants. Environ. Sci. Technol. 38, 3705-3712

Barnes JD, Denney RC, Mendham J, Thomas MJK (2005): Analyse chimique quantitative de Vogel. De Boeck Supérieur

Begum A, Gautam SK (2012): Endosulfan and lindane degradation using ozonation. Environ. Technol. 33, 943-949

Beurskens JEM, Stams AJM, Zehnder AJB, Bachmann A (1991): Relative biochemical reactivity of three hexachlorocyclohexane isomers. Ecotoxicol. Environ. Safety 21, 128-136

Brumblay RU (1971): Quantitative Analysis - College Outline. HarperCollins, New York

Cao J, Zhang WX, Brown DG, Sethi D (2008): Oxidation of lindane with Fe (II)-activated sodium persulfate. Environ. Eng. Sci. 25, 221-228

Cheng M, Zeng G, Huang D, Lai C, Xu P, Zhang C, Liu Y (2016): Hydroxyl radicals based advanced oxidation processes (AOPs) for remediation of soils contaminated with organic compounds: A review. Chem. Eng. J. 284, 582-598

Dubearnes B (2006): Site de Sierentz, Etude sur les mécanismes de transfert de la pollution. Etude réalisée par l'ADEME, 32-54

Hanna K, Lassabatere L, Bechet B (2012): Transport of two naphthoic acids and salicylic acid in soil: Experimental study and empirical modeling. Water Res. 46, 4457-4467

Johri AK, Dua M, Tuteja D, Saxena R, Saxena DM, Lal R (1998): Degradation of alpha, beta, gamma and delta-hexachlorocyclohexanes by Sphingomonas paucimobilis. Biotechnol. Lett. 20, 885-887

Jonsson S, Persson Y, Frankki S, van Bavel B, Lundstedt S, Haglund P, Tysklind M (2007): Degradation of polycyclic aromatic hydrocarbons (PAHs) in contaminated soils by Fenton's reagent: A multivariate evaluation of the importance of soil characteristics and PAH properties. J. Hazard. Mater. 149, 86-96

Kao CM, Huang KD, Wang JY, Chen TY, Chien HY (2008): Application of potassium permanganate as an oxidant for in situ oxidation of trichloroethylene-contaminated groundwater: A laboratory and kinetics study. J. Hazard. Mater. 153, 919-927

Khan S, He X, Khan HM, Boccelli D, Dionysiou DD (2016a): Efficient degradation of lindane in aqueous solution by iron (II) and/or UV activated peroxymonosulfate. J. Photochem. Photobiol. A. 316, 37-43

Khan S, He X, Khan JA, Khan HM, Boccelli DL, Dionysiou DD (2016b): Kinetics and mechanism of sulfate radical- and hydroxyl radical-induced degradation of highly chlorinated pesticide lindane in UV/peroxymonosulfate system. Chem. Eng. J. DOI: http://dx.doi.org/10.1016/j.cej.2016.05.150

Kong SH, Watts RJ, Choi JH (1998): Treatment of petroleum-contaminated soils using iron mineral catalyzed hydrogen peroxide. Chemosphere 37, 1473-1482

Laurent F, Cébron A, Schwartz C, Leyval C (2012): Oxidation of a PAH polluted soil using modified Fenton reaction in unsaturated condition affects biological and physicochemical properties. Chemosphere 86, 659-664

Lemaire J, Buès M, Kabeche T, Hanna K, Simonnot M-O (2013): Oxidant selection to treat an aged PAH contaminated soil by in situ chemical oxidation. J. Environ. Chem. Eng. $1,1261-1268$

Lewis J, Sjöstrom J (2010): Optimizing the experimental design of soil columns in saturated and unsaturated transport experiments. J. Contam. Hydrol. 115, 1-13 
Li S, Elliott DW, Spear ST, Ma L, Zhang W-X (2011): Hexachlorocyclohexanes in the Environment: Mechanisms of Dechlorination. Crit. Rev. Environ. Sci. Technol. 41, $1747-1792$

Manonmani HK (2011): Bioremediation of hexachlorocyclohexane contaminated soil: field trials. Pesticides in the modern world-pesticides use and management. InTech, New York, 475-504

Matta R, Hanna K, Kone T, Chiron S (2008): Oxidation of 2, 4, 6-trinitrotoluene in the presence of different iron-bearing minerals at neutral pH. Chem. Eng. J. 144, 453-458

Nienow AM, Bezares-Cruz JC, Poyer IC, Hua I, Jafvert CT (2008): Hydrogen peroxideassisted UV photodegradation of Lindane. Chemosphere 72, 1700-1705

Nitoi I, Oncescu T, Oancea P (2013): Mechanism and kinetic study for the degradation of lindane by photo-Fenton process. J. Ind. Eng. Chem. 19, 305-309

Palmroth MRT, Langwaldt JH, Aunola TA, Goi A, Puhakka JA, Tuhkanen TA (2006): Treatment of PAH-contaminated soil by combination of Fenton's reaction and biodegradation. J. Chem. Technol. Biotech. 81, 598-607

Peng L, Deng D, Guan M, Fang X, Zhu Q (2015): Remediation HCHs POPs-contaminated soil by activated persulfate technologies: Feasibility, impact of activation methods and mechanistic implications. Sep. Purif. Technol. 150, 215-222

Plassard F, Winiarski T, Petit-Ramel M (2000): Retention and distribution of three heavy metals in a carbonated soil: comparison between batch and unsaturated column studies. J. Contam. Hydrol. 42, 99-111

Romero A, Santos A, Vicente F, González C (2010): Diuron abatement using activated persulphate: Effect of pH, Fe(II) and oxidant dosage. Chem. Eng. J. 162, 257-265

Rusch B, Hanna K, Humbert B (2010): Sorption and Transport of Salicylate in a Porous Heterogeneous Medium of Silica Quartz and Goethite. Environ. Sci. Technol. 44, 2447-2453

Safarzadeh-Amiri A, Bolton JR, Cater SR (1996): The use of iron in advanced oxidation processes. J. Adv. Oxid. Technol. 18-26

Sirguey C, Tereza de Souza e Silva P, Schwartz C, Simonnot M-O (2008): Impact of chemical oxidation on soil quality. Chemosphere 72, 282-289

Tamura H, Kawamura S, Hagayama M (1980): Acceleration of the oxidation of $\mathrm{Fe} 2+$ ions by $\mathrm{Fe}(\mathrm{III})$-oxyhydroxides. Corros. Sci. 20, 963-971

Tseng D-H, Juang L-C, Huang H-H (2012): Effect of oxygen and hydrogen peroxide on the photocatalytic degradation of monochlorobenzene in aqueous suspension. Int. J. Photoenergy 2012

Usman M, Faure P, Ruby C, Hanna K (2012a): Remediation of PAH-contaminated soils by magnetite catalyzed Fenton-like oxidation. Appl. Catal. B, Environ. 117-118, 10-17

Usman M, Faure P, Ruby C, Hanna K (2012b): Application of magnetite-activated persulfate oxidation for the degradation of PAHs in contaminated soils. Chemosphere 87, 234240

Usman M, Tascone O, Faure P, Hanna K (2014): Chemical oxidation of hexachlorocyclohexanes (HCHs) in contaminated soils. Sci. Total Environ. 476-477, 434-439

Usman M, Hanna K, Haderlein S (2016a): Fenton oxidation to remediate PAHs in contaminated soils: A critical review of major limitations and counter-strategies. Sci. Total Environ. 569-570, 179-190

Usman M, Chaudhary A, Biache C, Faure P, Hanna K (2016b): Effect of thermal pretreatment on the availability of PAHs for successive chemical oxidation in contaminated soils. Environ. Sci. Pollut. Res. 23, 1371-1380 
Vijgen J, Abhilash P, Li Y, Lal R, Forter M, Torres J, Singh N, Yunus M, Tian C, Schäffer A, Weber R (2011): Hexachlorocyclohexane $(\mathrm{HCH})$ as new Stockholm Convention POPs - a global perspective on the management of Lindane and its waste isomers. Environ. Sci. Pollut. Res. 18, 152-162

Voldner EC, Li Y-F (1995): Global usage of selected persistent organochlorines. Sci. Total Environ. 160-161, 201-210

Wacławek S, Antoš V, Hrabák P, Černík M, Elliott D (2015): Remediation of hexachlorocyclohexanes by electrochemically activated persulfates. Environ. Sci. Pollut. Res. 23, 765-773.

Wacławek S, Antoš V, Hrabák P, Černík M (2016): Remediation of hexachlorocyclohexanes by cobalt-mediated activation of peroxymonosulfate. Desalin. Water Treat. 57, 2627426279

Wang G-S, Hsieh S-T, Hong C-S (2000): Destruction of humic acid in water by UV lightcatalyzed oxidation with hydrogen peroxide. Water Res. 34, 3882-3887

Weber JB, David MW (1982): Mobility of Herbicides in Soil Columns under Saturated- and Unsaturated-Flow Conditions. Weed Sci. 30, 579-584

Willett KL, Ulrich EM, Hites RA (1998): Differential Toxicity and Environmental Fates of Hexachlorocyclohexane Isomers. Environ. Sci. Technol. 32, 2197-2207

Yan YE, Schwartz FW (1999): Oxidative degradation and kinetics of chlorinated ethylenes by potassium permanganate. J. Contam. Hydrol. 37, 343-365

Zhao D, Liao X, Yan X, Huling SG, Chai T, Tao H (2013): Effect and mechanism of persulfate activated by different methods for PAHs removal in soil. J. Hazard. Mater. 254-255, 228-235 
Table 1: Details of chemical oxidation treatments employed in no-flow and column studies.

\begin{tabular}{|c|c|c|c|c|c|}
\hline \multicolumn{6}{|c|}{ Batch experiment I: Effect of oxidant dose } \\
\hline \multicolumn{3}{|l|}{ Oxidant } & Test & $\begin{array}{l}\text { Oxidant } \\
\text { dose }\end{array}$ & $\begin{array}{l}\text { Catalyst dose } \\
\left(\mathrm{Fe} \mathrm{e}^{\prime \prime}\right)\end{array}$ \\
\hline \multicolumn{3}{|c|}{ Hydrogen peroxide $\left(\mathrm{H}_{2} \mathrm{O}_{2}\right)$} & - & $900 \mathrm{mM}$ & $0 \mathrm{mM}$ \\
\hline \multirow{3}{*}{\multicolumn{3}{|c|}{ Fenton $\left(\mathrm{H}_{2} \mathrm{O}_{2} / \mathrm{Fe}^{\| \prime}\right)$}} & A & $200 \mathrm{mM}$ & $20 \mathrm{mM}$ \\
\hline & & & $\bar{B}$ & $600 \mathrm{mM}$ & $60 \mathrm{mM}$ \\
\hline & & & $\mathrm{C}$ & $900 \mathrm{mM}$ & $90 \mathrm{mM}$ \\
\hline \multicolumn{3}{|c|}{ Sodium persulfate $\left(\mathrm{Na}_{2} \mathrm{~S}_{2} \mathrm{O}_{8}\right)$} & - & $600 \mathrm{mM}$ & $0 \mathrm{mM}$ \\
\hline \multirow{3}{*}{\multicolumn{3}{|c|}{ Activated Persulfate $\left(\mathrm{Na}_{2} \mathrm{~S}_{2} \mathrm{O}_{8} / \mathrm{Fe}^{\prime \prime}\right)$}} & A & $100 \mathrm{mM}$ & $50 \mathrm{mM}$ \\
\hline & & & $B$ & $300 \mathrm{mM}$ & $150 \mathrm{mM}$ \\
\hline & & & C & $600 \mathrm{mM}$ & $300 \mathrm{mM}$ \\
\hline \multirow{2}{*}{\multicolumn{6}{|c|}{\begin{tabular}{|l|l|} 
Reference (Blank) & Blank \\
Batch experiment II: Effect of solid loading/particle size
\end{tabular}}} \\
\hline & & & & & \\
\hline \multicolumn{2}{|c|}{ Solid loading } & Particle size & Oxidant & $\begin{array}{l}\text { Oxidant } \\
\text { dose }\end{array}$ & $\begin{array}{l}\text { Catalyst dose } \\
\left(\mathrm{Fe}^{\prime \prime}\right)\end{array}$ \\
\hline \multirow{5}{*}{\multicolumn{2}{|c|}{$\begin{array}{l}5 \mathrm{~g} \text { or } \\
10 \mathrm{~g} \text { or } \\
20 \mathrm{~g}\end{array}$}} & \multirow{5}{*}{$\begin{array}{l}500 \mu \mathrm{m} \text { or } \\
2 \mathrm{~mm} \text { or } \\
5 \mathrm{~mm}\end{array}$} & $\mathrm{H}_{2} \mathrm{O}_{2}$ & $600 \mathrm{mM}$ & $0 \mathrm{mM}$ \\
\hline & & & $\mathrm{H}_{2} \mathrm{O}_{2} / \mathrm{Fe}^{\| I}$ & $600 \mathrm{mM}$ & $60 \mathrm{mM}$ \\
\hline & & & $\mathrm{Na}_{2} \mathrm{~S}_{2} \mathrm{O}_{8}$ & $300 \mathrm{mM}$ & $0 \mathrm{mM}$ \\
\hline & & & $\mathrm{Na}_{2} \mathrm{~S}_{2} \mathrm{O}_{8} / \mathrm{Fe}^{\mathrm{ll}}$ & $300 \mathrm{mM}$ & $150 \mathrm{mM}$ \\
\hline & & & Blank & No oxidant & $0 \mathrm{mM}$ \\
\hline \multicolumn{6}{|c|}{ Column experiment I: Effect of flow rate (saturated conditions) } \\
\hline $\begin{array}{l}\text { Solid } \\
\text { loading }\end{array}$ & $\begin{array}{l}\text { Flow } \\
\text { rate }\end{array}$ & Particle size & Oxidant & $\begin{array}{l}\text { Oxidant } \\
\text { dose }\end{array}$ & $\begin{array}{l}\text { Catalyst dose } \\
\left(F e^{\prime \prime}\right)\end{array}$ \\
\hline \multirow{6}{*}{$20 \mathrm{~g}$} & \multirow{6}{*}{$\begin{array}{l}0.5 \\
\mathrm{~mL} / \mathrm{min} \\
\text { or } \\
2 \\
\mathrm{~mL} / \mathrm{min}\end{array}$} & \multirow{6}{*}{$\begin{array}{l}500 \mu \mathrm{m} \text { or } 2 \mathrm{~mm} \text { or } \\
500 \mu \mathrm{m} \text { samples } \\
\text { mixed with sand } \\
(30 \% \mathrm{w} / \mathrm{w})\end{array}$} & $\mathrm{H}_{2} \mathrm{O}_{2}$ & $600 \mathrm{mM}$ & $0 \mathrm{mM}$ \\
\hline & & & $\mathrm{H}_{2} \mathrm{O}_{2} / \mathrm{Fe}^{\mathrm{II}}$ & $600 \mathrm{mM}$ & $60 \mathrm{mM}$ \\
\hline & & & $\mathrm{Na}_{2} \mathrm{~S}_{2} \mathrm{O}_{8}$ & $300 \mathrm{mM}$ & $0 \mathrm{mM}$ \\
\hline & & & $\mathrm{Na}_{2} \mathrm{~S}_{2} \mathrm{O}_{8} / \mathrm{Fe}^{\mathrm{II}}$ & $300 \mathrm{mM}$ & $60 \mathrm{mM}$ \\
\hline & & & $\mathrm{KMnO}_{4}$ & $90 \mathrm{mM}$ & $0 \mathrm{mM}$ \\
\hline & & & Blank & No oxidant & $0 \mathrm{mM}$ \\
\hline \multicolumn{6}{|c|}{ Column experiment II: Effect of oxidant dose (saturated columns) } \\
\hline $\begin{array}{l}\text { Solid } \\
\text { loading }\end{array}$ & $\begin{array}{l}\text { Flow } \\
\text { rate }\end{array}$ & Particle size & Oxidant & $\begin{array}{l}\text { Oxidant } \\
\text { dose }\end{array}$ & $\begin{array}{l}\text { Catalyst dose } \\
\left(\mathrm{Fe}^{\prime \prime}\right)\end{array}$ \\
\hline \multirow{9}{*}{$20 \mathrm{~g}$} & \multirow{9}{*}{$\begin{array}{l}0.5 \\
\mathrm{~mL} / \mathrm{min}\end{array}$} & \multirow{9}{*}{$2 \mathrm{~mm}$} & \multirow{3}{*}{$\mathrm{H}_{2} \mathrm{O}_{2}$} & $200 \mathrm{mM}$ & $0 \mathrm{mM}$ or $60 \mathrm{mM}$ \\
\hline & & & & $600 \mathrm{mM}$ & $0 \mathrm{mM}$ or $60 \mathrm{mM}$ \\
\hline & & & & $900 \mathrm{mM}$ & $0 \mathrm{mM}$ or $60 \mathrm{mM}$ \\
\hline & & & \multirow{3}{*}{$\mathrm{Na}_{2} \mathrm{~S}_{2} \mathrm{O}_{8}$} & $100 \mathrm{mM}$ & $0 \mathrm{mM}$ or $60 \mathrm{mM}$ \\
\hline & & & & $300 \mathrm{mM}$ & $0 \mathrm{mM}$ or $60 \mathrm{mM}$ \\
\hline & & & & $600 \mathrm{mM}$ & $0 \mathrm{mM}$ or $60 \mathrm{mM}$ \\
\hline & & & \multirow{2}{*}{$\mathrm{KMnO}_{4}$} & $30 \mathrm{mM}$ & $0 \mathrm{mM}$ \\
\hline & & & & $90 \mathrm{mM}$ & $0 \mathrm{mM}$ \\
\hline & & & Blank & No oxidant & $0 \mathrm{mM}$ \\
\hline \multicolumn{6}{|c|}{ Column experiment III: Chemical oxidation under unsaturated columns } \\
\hline $\begin{array}{l}\text { Solid } \\
\text { loading }\end{array}$ & \begin{tabular}{|l|l} 
Flow \\
rate
\end{tabular} & Particle size & Test & $\begin{array}{l}\text { Oxidant } \\
\text { dose }\end{array}$ & $\begin{array}{l}\text { Catalyst dose } \\
\left(\mathrm{Fe}^{\prime \prime}\right)\end{array}$ \\
\hline \multirow{4}{*}{$20 \mathrm{~g}$} & \multirow{4}{*}{$\begin{array}{l}0.5 \\
\mathrm{~mL} / \mathrm{min}\end{array}$} & \multirow{4}{*}{$2 \mathrm{~mm}$} & $\mathrm{H}_{2} \mathrm{O}_{2}$ & $600 \mathrm{mM}$ & $0 \mathrm{mM}$ or $60 \mathrm{mM}$ \\
\hline & & & $\mathrm{Na}_{2} \mathrm{~S}_{2} \mathrm{O}_{8}$ & $100 \mathrm{mM}$ & $0 \mathrm{mM}$ \\
\hline & & & $\mathrm{KMnO}_{4}$ & $30 \mathrm{mM}$ & $0 \mathrm{mM}$ \\
\hline & & & Blank & No oxidant & $0 \mathrm{mM}$ \\
\hline
\end{tabular}


Table 2: Summary of the column characteristics.

Experimental I and II Experimental III (saturated columns) (unsaturated columns)

Soil weight, $g$ 20 20

Column section, $\mathrm{cm}^{2}$ Height of bed, $\mathrm{cm}$ 4.9 4.9

Bed density $\rho, \mathrm{g} \mathrm{cm}^{3}$ 3.5

1.16

3.5

Pore volume $\mathrm{Vp}, \mathrm{mL}$

Flow rate, $\mathrm{ml} \mathrm{min}^{-1}$

7.8

1.16

Porosity, $\theta$

$0.5 ; 2$

5.9

0.45

0.5

$\mathrm{Q}, \mathrm{cm} \mathrm{min}^{-1}$

$0.1 ; 0.4$

0.34

Velocity, $\mathrm{cm} \mathrm{min}^{-1}$

$0.22 ; 0.88$

0.29 


\section{Figure captions:}

Figure 1: Degradation of $\beta-\mathrm{HCH}$ and lindane after chemical oxidation by: $\mathrm{H}_{2} \mathrm{O}_{2}$ alone (900 $\mathrm{mM})$ without iron activation and Fenton oxidation $\left(\mathrm{H}_{2} \mathrm{O}_{2} / \mathrm{Fe}^{\mathrm{II}}\right)$ by using $200 \mathrm{mM} \mathrm{H} \mathrm{H}_{2}+20$ $\mathrm{mM}$ soluble $\mathrm{Fe}^{\mathrm{II}}$ (dose $\mathrm{A}$ ), $600 \mathrm{mM} \mathrm{H} \mathrm{O}_{2}+60 \mathrm{mM}$ soluble $\mathrm{Fe}^{\mathrm{II}}$ (dose $\mathrm{B}$ ), $900 \mathrm{mM} \mathrm{H} \mathrm{H}_{2} \mathrm{O}_{2}+90$ $\mathrm{mM}$ soluble $\mathrm{Fe}^{\mathrm{II}}$ (dose $\mathrm{C}$ ), sodium persulfate alone $(600 \mathrm{mM})$ without iron activation $\left(\mathrm{Na}_{2} \mathrm{~S}_{2} \mathrm{O}_{8}\right)$, and activated persulfate $\left(\mathrm{Na}_{2} \mathrm{~S}_{2} \mathrm{O}_{8} / \mathrm{Fe}^{\mathrm{II}}\right)$ by using $100 \mathrm{mM} \mathrm{Na} 2 \mathrm{~S}_{2} \mathrm{O}_{8}+50 \mathrm{mM}$ soluble $\mathrm{Fe}^{\mathrm{II}}$ (dose $\mathrm{A}$ ), $300 \mathrm{mM} \mathrm{Na} \mathrm{S}_{2} \mathrm{O}_{8}+150 \mathrm{mM}$ soluble $\mathrm{Fe}^{\mathrm{II}}$ (dose $\mathrm{B}$ ) and $600 \mathrm{mM}$ sodium persulfate $+300 \mathrm{mM}$ soluble $\mathrm{Fe}^{\mathrm{II}}$ (dose C). Quantification of $\mathrm{HCH}$ isomer was performed by GC-MS. Values corresponding to the dose $\mathrm{B}$ of $\mathrm{H}_{2} \mathrm{O}_{2} / \mathrm{Fe}^{\mathrm{II}}$ and that of $\mathrm{Na}_{2} \mathrm{~S}_{2} \mathrm{O}_{8} / \mathrm{Fe}^{\mathrm{II}}$ were borrowed from previous study (Usman et al. 2014).

Figure 2: Degradation of $\beta-\mathrm{HCH}$ in contaminated soil (sieved through $2 \mathrm{~mm}$ mesh size) under saturated column conditions at two different flow rates $(0.5 \mathrm{~mL} / \mathrm{min}$ and $2 \mathrm{~mL} / \mathrm{min})$ after chemical oxidation by: $600 \mathrm{mM} \mathrm{H}_{2} \mathrm{O}_{2}$, Fenton oxidation by using $600 \mathrm{mM} \mathrm{H} \mathrm{H}_{2}+60$ $\mathrm{mM}$ soluble $\mathrm{Fe}^{\mathrm{II}}\left(\mathrm{H}_{2} \mathrm{O}_{2} / \mathrm{Fe}^{\mathrm{II}}\right), 300 \mathrm{mM}$ sodium persulfate alone $\left(\mathrm{Na}_{2} \mathrm{~S}_{2} \mathrm{O}_{8}\right)$, activated persulfate by using $300 \mathrm{mM}$ sodium persulfate $+60 \mathrm{mM}$ soluble $\mathrm{Fe}^{\mathrm{II}}\left(\mathrm{Na}_{2} \mathrm{~S}_{2} \mathrm{O}_{8} / \mathrm{Fe}^{\mathrm{II}}\right)$ and $90 \mathrm{mM}$ of $\mathrm{KMnO}_{4}$. Quantification of $\mathrm{HCH}$ isomer was performed by GC-MS.

Figure 3: Effect of oxidant dose on the degradation of $\beta-\mathrm{HCH}$ in contaminated soil (sieved through $2 \mathrm{~mm}$ mesh size) under saturated column conditions (flow rate of $0.5 \mathrm{~mL} / \mathrm{min}$ ) as evaluated with following chemical oxidant doses: $200 \mathrm{mM} \mathrm{H}_{2} \mathrm{O}_{2}$ (dose A), $600 \mathrm{mM} \mathrm{H} \mathrm{H}_{2} \mathrm{O}_{2}$ (dose B), $900 \mathrm{mM} \mathrm{H} \mathrm{O}_{2}$ (dose C), $100 \mathrm{mM} \mathrm{Na}_{2} \mathrm{~S}_{2} \mathrm{O}_{8}$ (dose A), $300 \mathrm{mM} \mathrm{Na} 2 \mathrm{~S}_{2} \mathrm{O}_{8}$ (dose B),

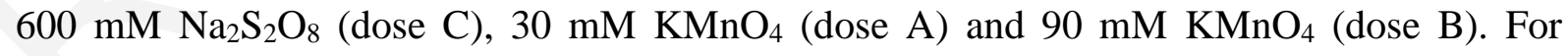
comparison, soluble $\mathrm{Fe}^{\mathrm{II}}(60 \mathrm{mM})$ was also used as a catalyst with all tested quantities of $\mathrm{H}_{2} \mathrm{O}_{2}$ and $\mathrm{Na}_{2} \mathrm{~S}_{2} \mathrm{O}_{8}$. Quantification of $\mathrm{HCH}$ isomer was performed by GC-MS.

Figure 4: Comparison of (a) degradation of $\beta-\mathrm{HCH}$ in contaminated soil (sieved through 2 mm mesh size) and (b) decomposition extent of oxidant as a function of column under 
saturated vs. unsaturated conditions tested with following two oxidants: $100 \mathrm{mM}$ sodium persulfate $\left(\mathrm{Na}_{2} \mathrm{~S}_{2} \mathrm{O}_{8}\right)$ and $30 \mathrm{mM}$ potassium permanganate $\left(\mathrm{KMnO}_{4}\right)$. Unsaturated conditions were maintained by sprinkling oxidant solutions on contaminated soils with a constant flow rate of $0.5 \mathrm{~mL} / \mathrm{min}$. 
Figure 1:

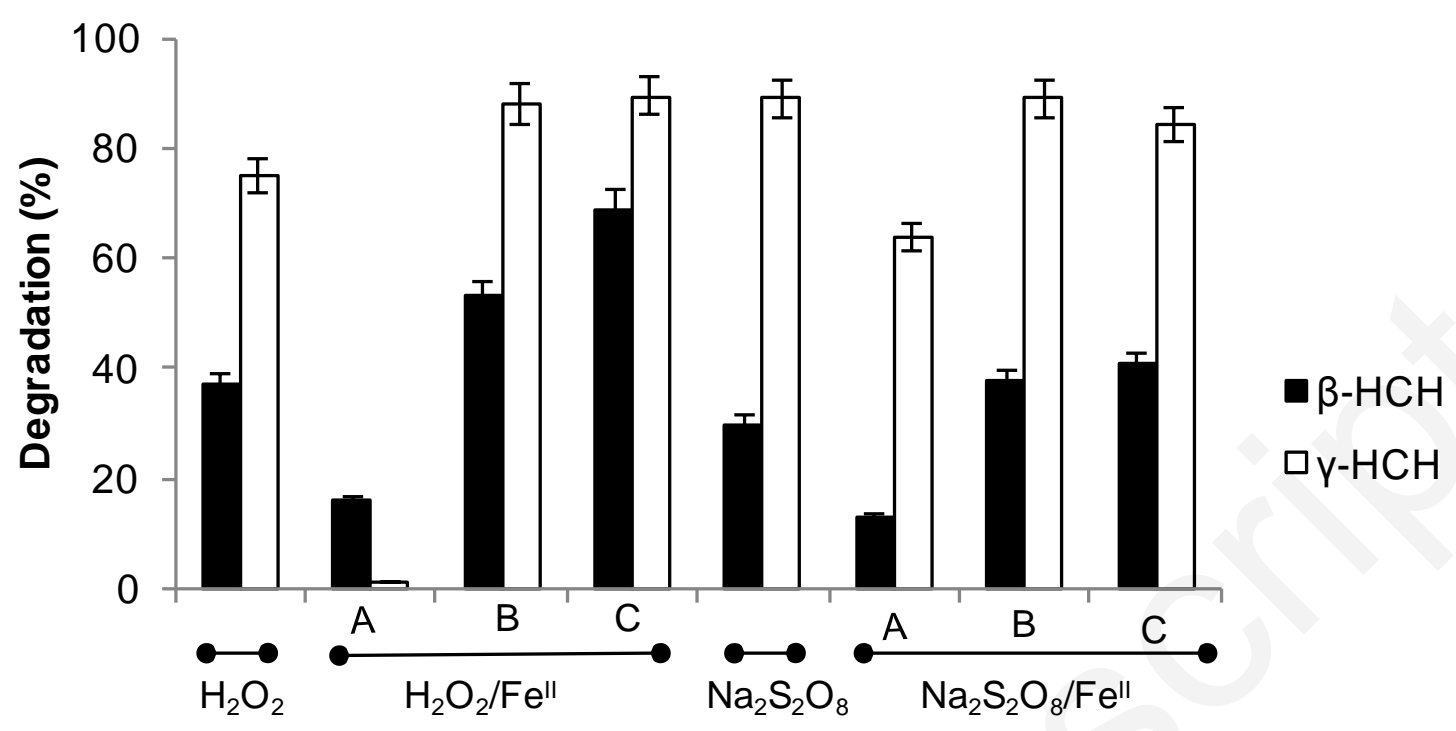


Figure 2:

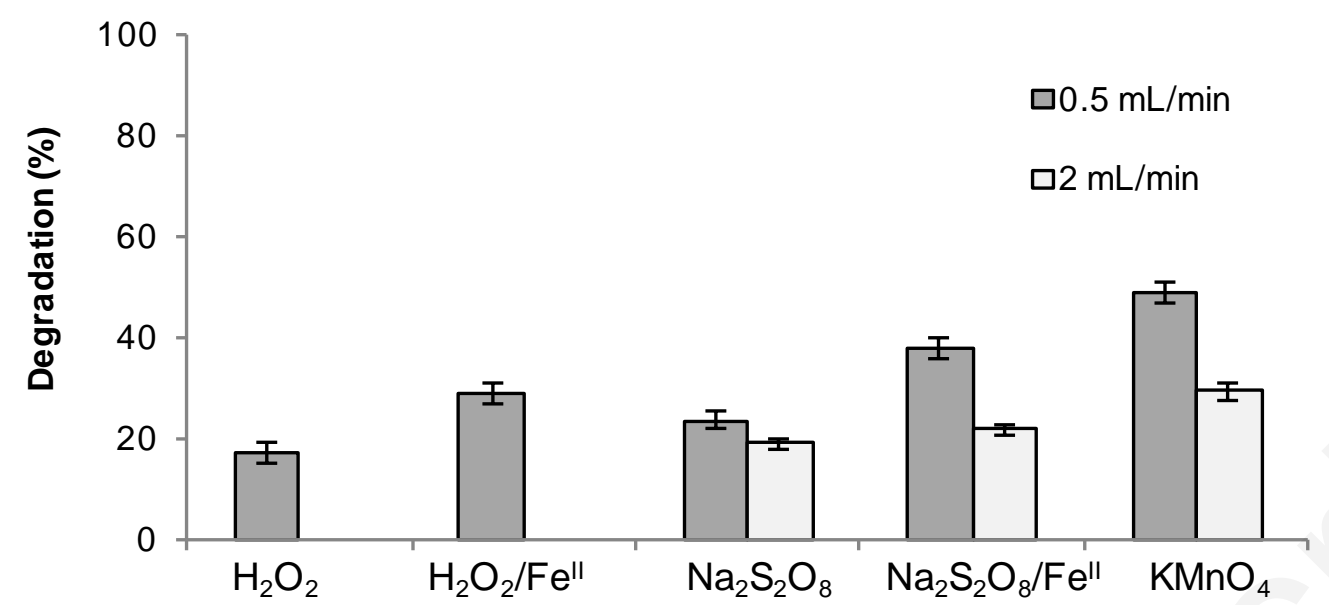


Figure 3:

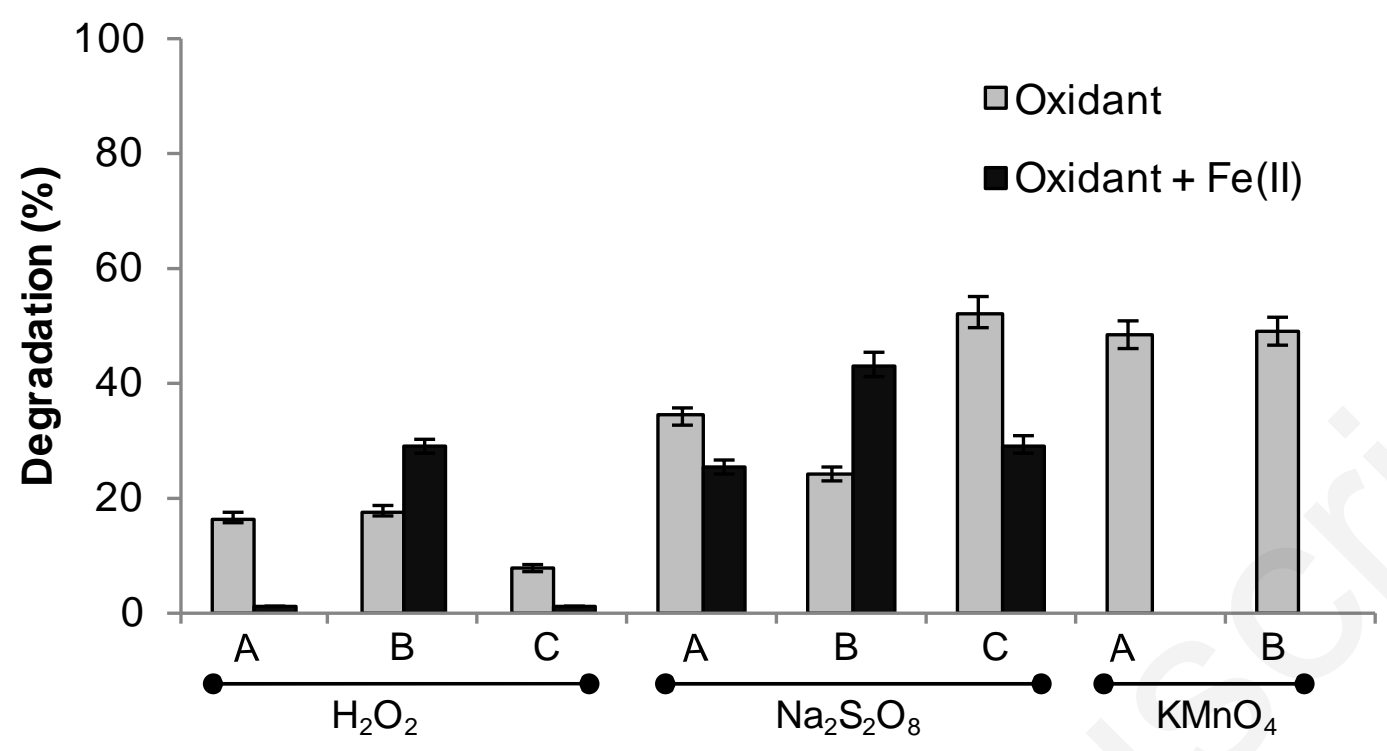


Figure 4:
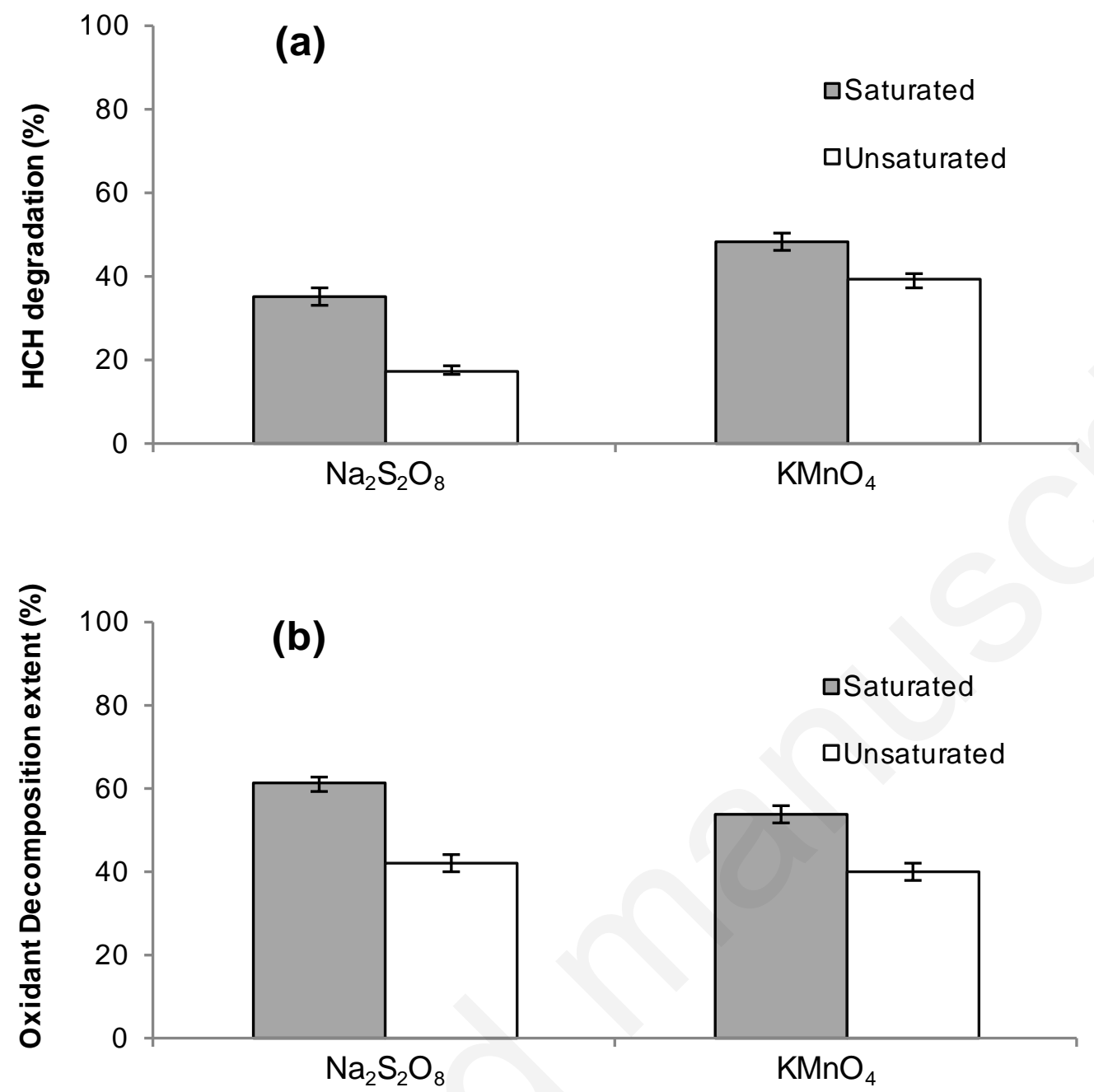